\title{
Country Risk Modeling in Indonesia: An Empirical Approach
}

\author{
Muhammad Adnan $^{1 *}$, Sri Maemunah ${ }^{2}$, Fitri Ismiyanti ${ }^{2} \&$ Rudi Purwono ${ }^{2}$ \\ ${ }^{1}$ Faculty of Islamic Economic and Business \\ The State Islamic University of Ar-Raniry \\ Banda Aceh, Indonesia \\ ${ }^{2}$ Faculty of Economic and Business, \\ Airlangga University, Surabaya, Indonesia \\ *Corresponding Author: Faculty of Islamic Economic and Business, The State Islamic \\ University of Ar-Raniry, Banda Aceh - Indonesia. E-mail: mhd_adnan@ymail.com
}

Received: July 23, 2014 Accepted: Nov. 11, $2014 \quad$ Published: June 1, 2015

doi:10.5296/ajfa.v7i1.6694 URL: http://dx.doi.org/10.5296/ajfa.v7i1.6694

\begin{abstract}
This study is intended to analyze the influence of internal and external risk factors considered relevant influencing the country risk. We find result of long term VECM estimation indicating that the exchange rate, the interest rate of certificate of Bank Indonesia (SBI) for 6 months and the world economic growth have positive and significant influence to country risk. Inflation, Indonesia economic growth, the Fed, and MSCI ACWI IMI return have negative and significant influence to country risk. All hypotheses presented in this study are theoretically and statistically accepted, except that the hypothesis on inflation is rejected because it is in controversy with theory, although statistically it has significant influence to the country risk in Indonesia.

Meanwhile the estimated output of VECM in a short term, the exchange rate, the interest rate of SBI for 6 months and the world economic growth have positive and significant influence to country risk. The Fed and MSCI ACWI IMI return have negative and significant influence to country risk. The hypotheses testing accepted from the estimated VECM in short term are the exchange rate, the SBI interest rate in 6 months, the Fed, the world economic growth and the return of MSCI ACWI IMI.
\end{abstract}

Keywords: Country Risk, Country Beta Approach, Risk Factors, Indonesia, VECM 


\section{Introduction}

The aim of investors to make investment is to maximize the level of profits (return) without neglecting the risk factors they have to bear. Return is the output obtained from investment, so that the presence of return will motivate investors to invest. In addition, investors have to be able to calculate the risk of an investment, because the risk level contains possibility of the deviation of the realization return from the expected return. Preferences of investors to the risk vary, because not all investors like the risk.

The traditional portfolio theory states that the risk in security is classified into two categories, namely market risk and company risk (Schill, 2008). The market risk is measured by the trend of the stocks moving together, whereas the company risk is more related to certain company. The total portfolio risks borne by the investors consist of the systematic risk and non-systematic risk (Ross et al. 2009, p. 292). The market risk also called systematic risk constitutes the risks related to the changes at the market as a whole. Such a market change can influence variability of return of an investment. This systematic risk can be measured by using the Beta (B) Coefficient. Beta indicates the sensitivity of security return to the change in market return.

In the context of international diversification, Beta indicates sensitivity of profit level index of a certain country to the level of portfolio profit of the world market. Investors can and will carry out the international diversification. This proves that the stock market of a country is integrated to the world stock markets. This study uses the term country risk, in which the country risk is a systematic risk of an international portfolio. Country risk was a covariant of security return of a certain country to the security return of global market (Harvey, 1991). Verma and Soydemir (2006) said that in the perspective of foreign investors, the country risk evaluation was urgently needed because it concerns with the cross-country investment.

Harvey (1991) introduced the model of country risk beta approach constituting the extension Capital Asset Pricing Model (CAPM) by Sharpe (1964), Lintner (1965), and Mossin (1966) and a cornerstone in investment theory. This CAPM theory was a development of Markowitz's portfolio theory based on the trade-off between the risk and the return having the linear and positive nature. The CAPM assumed that under equilibrium conditions, expected return represent fair compensation for the degree of risk security contributed to a broad market portfolio (Bruner et al., 2008).

This country risk approach was a quantitative method by using the beta coefficient in which the said beta represented the time-varying parameter of a function of a number of economic and financial independent variables (Verbenik et al., 2011). Jagannathan and Wang (1996) were in the opinion that the time-varying beta derives from the special issues at the company and the economic condition as a whole. Further, Teixeira et al. (2008) states that time-varying parameter was influenced by the internal and external risk factors. Oetzel et al. (2001), Abel and Kruger (1989) stated that the macroeconomic variables constitute the most potential factor influencing the time-varying beta. 
Some empirical studies having applied the country beta approach were Harvey and Zhou (1993), Erb et al. (1996a, 1996b), Gangemi et al. (2000), Andrade and Teles (2006), Verma and Soydemir (2006), Basu et al. (2011), and the latest was Verbenik et al. (2011). Output of the previous research indicated that the relation between country risk and internal and external macroeconomic variables varied. This was caused by relevant macroeconomic variables between the different developed market and the emerging market.

This research estimates several internal and external macroeconomic variables considered relevant influencing the country risk in Indonesia, by using the econometric approach under Vector Error Correction Model (VECM) method. The remaining of the paper is organized as follow: Section 2 literature study and empirical study. Section 3 presents hypotheses development. Section 4 describes methodology and the econometric methodology. Section 5 report result and estimation. The final section is the conclusion.

\section{Literature Study and Empirical Study}

Investment conducted at the stock market is an investment full of uncertainties, because the securities sold and purchased at the stock market contains the risks and uncertain level of return. Before making investment, the multinational companies or foreign investors had better consider first the political stability and macroeconomic condition of the country becoming the destination of their investment, because it has the impact on the risk level and the return to be received.

Harvey (1991) stated that country risk was as conditional sensitivity (or covariance) of the country return to world stock return. Gangemi et al. (2000) stated that the country risk constituted the exposure function of a country to the world market. Verma and Soydemir (2006) added that the country risk was a risk arising as the effect of investors conducting the international investment. This is a non-systematic risk (unique risk), if it is observed from the view point of foreign investors making investment in other countries. However, when it is observed from the view point of domestic investor, this is a systematic risk. Based on various definitions above, it can be concluded that the beta concept or the country risk constitutes the beta (B) systematic risk, in which this risk appears when the investors make investment in different countries or making the international diversification.

According to Sharpe (1964) and Lintner (1965), beta was a focal point of investment and financing decision. Beta is a systematic risk parameter of a security that cannot be omitted by doing diversification. Akdeniz et al. (2003) beta risk changed through time with the changes in the economic environment and the dynamics of time variation of beta differsed across industries. In addition, beta indicates the sensitivity of security return to the change of market return. Under a CAPM equilibrium model, the beta value influences a great deal to the level of the expected profit of a security. The higher the value of beta and the market return are, the higher level of return signaled by the investors.

Country risk is influenced by the internal and external risk factors. This internal risk factor refers to the specific factors influencing the country risk related to the economic fundaments of a certain country, rate of exchange, such as inflation, economic growth, amount of money 
in circulation (money supply), and many others. The external risk also covers all factors of global risks in which if the changes occur on such factors, they will have a domino effect to the world economic activities, such as world price increase and development of stock return from the stock market becoming the standard of the world investment and the USA's monetary policy to the Fed (Ferson and Harvey (1994), Min (1999), Grandes (2002), and Teixeira (2008).

Several studies already been carried out to estimate the country risk by using the country beta approach method introduced by Harvey (1991). Harvey and Zhou (1993) carried out country risk estimation in 17 (seventeen) developing countries on the effect of portfolio of the world market. Erb et al. (1996a) estimated the country risks for 117 (one hundred seventeen) countries during the period of 1984 - 1995 by investigating the 5 (five) sources of risks (political, financial, economic, composite risk index and credit ratings). Their finding stated that there was a relationship between country risk and the future stock return. Further, Erb et al. (1996b) also analyzed the country beta as a function of country credit risk in 21 (twenty one) developed markets and 26 (twenty six) emerging markets during the period of 1979-1995. The finding of their study stated that the political risk, inflation, rate of exchange, industrial portfolio and economic growth simultaneously influence the country's credit rating.

Gangemi et al. (2000) analyzed the impact of macroeconomic focusing on the open economic variables to the Australia's country risk. The finding of their study indicated that only the trade weighted of exchange rate significantly influences the country beta in Australia. Andrade and Teles (2006) analyzed the influence of macroeconomic variables to the country risk of Brazil by using a time-varying parameter approach. Output of their study indicated that the monetary policy of this country represented by the rate of interest significantly influenced the country risk of Brazil and international reserve had a significant impact only in fixed exchange rate period.

Verma and Soydemir (2006) investigated the local factors and the global factors influencing the country risk of Latin America. Output of their study indicated that those two factors had relatively different influence to the country risk of Latin America. The Global factor, namely the real interest and inflation of G-7 Countries had negative influence to the country beta of Mexico, followed by Brazil and Chile. Money supply was a very influential local factor to the country risk of Mexico and followed by Chile and Brazil, whereas the exchange rate only gave the influence to Mexico and Brazil but not to Argentina and Chile.

Basu et al. (2011) used some macroeconomic indicators and political risk to make estimation on India country risk. The output of his study indicated that the country risk of India was very much influenced by FDI Inflow, rate of interest, rate of exchange, and level of unemployment. Verbenik et al. (2011) estimated the country risk of New European Union Member States by using the local and global risk factors. Output of their study was that on the fourth quarter of the year 2008, during the occurrence of economic crisis, it causes the country risk of the New EU Member States increased. The beta coefficient of the New European Union Member States significantly was more influenced by the global risk factor rather than the domestic one. 


\section{Hypotheses Development}

Portfolio theory of Markowitz states that the relationship between the risk and the return of an investment is in the same direction and positive. Based on the said model, each investor is assumed that he will diversify his portfolio and will choose the portfolio on his preference upon return and risk. The CAPM was a simple and stable linear relationship between an asset's systematic risk and its expected return (Akdeniz et al., 2003).

The Beta Coefficient constituting the systematic risk was influenced by the business cycle (Jagannathan and Wang, 1996). The less stable, the local and the global macroeconomic condition was, the bigger influence the investors would get to make investment in a certain country. Some hypotheses able to be presented in this study related to the influence of internal and external macroeconomic factors to the country beta in Indonesia are as follows:

The change in rate of exchange to USD, either due to appreciation or depreciation will influence the activities of export and investment in a country, because at present the USD is still a currency dominating the global payment and global commercial transactions. Some empirical studies conducted by Min (1998), Abel and Krueger (1989), Gangemi et al. (2000), Bilson et al. (2001), Jeon (2001), Wdowinski (2004), Verbenik et al. (2011), and also Topak and Muzir (2011) stated that the rate of exchange significantly influenced the country risk of a certain country.

\section{H-1: The exchange rate of Rupiah to USD has positive influence to the country risk in Indonesia.}

The interest rate is one of the monetary instruments frequently used by Bank Indonesia as a means of monetary control. The change of interest rate of SBI (Certificate of Bank Indonesia) is potential to increase or decrease the investment risk at the stock market. The study by Abel and Krueger (1989), and Verbenik et al. (2011) stated that the interest rate significantly influenced the country risk.

\section{H-2: Interest rate of SBI for 6 months has positive influence to the country risk in Indonesia.}

Inflation influences the economy of a country, because the change in inflation rate illustrates the stability or the failure of the macroeconomic policy of a country. The impact of the price increase of the goods gives influence to the return received by the company or the investors. According to Barro and Gordon (1983), inflation had the impact to the economy of a country. The high level of inflation could reduce the level of actual income or profits of the Investors.

\section{H-3: Inflation has positive influence to the country risk in Indonesia.}

The economic growth of a country is frequently used as a macroeconomic barometer to predict the investment condition in a certain country. The increase of economic growth of a country can increase the income per capita of the community so that their purchasing power increases and in the end it increases the company profitability. Some studies conducted by Kharas (1984), Abel and Krueger (1989), Soussanov (2002), Grandes (2002), Vij and Kapoor 
(2007), also Topak and Muzir (2011) declared that the relationship between Gross Domestic Product (GDP) and country risk was negative.

H-4: Indonesian economic growth has negative influence to the country risk in Indonesia.

The increase of the world oil price also gives pressure to the exchange rate so that it increases the demand for foreign currency from the economic doers in order to fulfill their import needs, so that the increase of oil price is a bad news for the market in general and has negative impact to the movement of stock price. The uncertainty of this world oil price makes the investors more doubtful to make investment at the stock market, so that it gives impact to the economy of the said country. The studies conducted by Verma and Soydemir (2006), and Verbenik et al. (2011) stated that the global factor gave more influence to the country risk of the said country.

\section{H-5: The world oil price has positive influence to the country risk in Indonesia.}

The increase of the Fed decreases the stock prices in US, so that it makes the global market doers withdraw their investment from the US Stock Market and transfer them to some other stock markets potentially giving the profits. Verma and Soydemir (2006) said that the influence of the US interest rate to the country risk was negative

\section{H-6: The Fed has negative influence to the country risk in Indonesia.}

The slowing down of the economy of the advanced countries gives impact to the slower down of the economic growth of the emerging market countries. The Indonesia stock market is an inseparable part of the global stock market activities, so that its development is very vulnerable to the macroeconomic condition in general. This indicates that there is a domino effect (contagion effect) of a certain country to the other countries which is able to influence the economic condition or stock market of the other countries.

\section{H-7: The world economic has positive influence to country risk in Indonesia.}

The foreign transaction also gives a contribution in determining the stock price movement in Indonesia. During the time of the increase of foreign capital inflow to Indonesia, it is also a positive signal for the domestic investors and the stock market, because the foreign capital inflow into Indonesia will attract the domestic investors to invest. The foreign transaction disparity between the net purchase and the net sale will be able to influence the IHSG (Composite Stock Price Index).

\section{H-8: Foreign transaction value has negative influence to country risk in Indonesia.}

The Indonesian stock market through the Indonesian Stock Exchange is the inseparable part of the global stock exchange activities. The world stock index, such as MSCI ACWI IMI constituting the benchmark of the world stock market, is expected to be able to illustrate the real condition of the world stock exchange. The high return of MSCI illustrates the condition of the world stock exchange which tends to be bullish, or the contrary - the low return of MSCI ACWI IMI illustrates the world stock exchange conditions having the tendency to be 


\section{Macrothink}

Asian Journal of Finance \& Accounting

ISSN 1946-052X

2015, Vol. 7, No. 1

bearish, so that it is surely confirmed to make investment at the stock exchange having the high risk.

\section{H-8: The return of MSCI ACWI IMI has negative influence to country risk in Indonesia.}

\section{Methodology}

\subsection{Data and Source}

The data applied in this study is the quarterly time series during period of 2004-2013. Data are obtained from Bank Indonesia (BI), Central Bureau of Statistics (BPS), International Financial Statistics (IFS) and Morgan Stanley Capital International (MSCI), and also Indonesia Stock Exchange (IDX). The description of the variables and data source is as follows:

Table 1. Internal and External Risk Factors

\begin{tabular}{|c|l|c|}
\hline \multicolumn{2}{|l|}{ Internal Factor } & Data Source \\
\hline Acronym & Description & IDX \\
\hline IHSG & Composite Stock Price Index & BI \\
\hline NTR & Exchange Rate of Rupiah to USD & BI \\
\hline SBI & $\begin{array}{l}\text { Interest Rate of SBI (Certificate of Bank Indonesia) in } \\
\text { Months }\end{array}$ & BPS \\
\hline INF & Consumer Price Index & BPS \\
\hline GRINDO & Indonesian Economic Growth & Data Source \\
\hline External Factor & IFS \\
\hline Acronym & Description & IFS \\
\hline OIL & The World Oil Price & IFS \\
\hline FED & Fed Fund Rate & MSX \\
\hline GRDUNIA & The World Economic Growth \\
\hline FNBS & Foreign Transaction Value & \\
\hline MSCI & $\begin{array}{l}\text { Morgan Stanley Capital International All Country World } \\
\text { Index Investable Market Index (MSCI ACWI IMI) }\end{array}$ & MSCI \\
\hline
\end{tabular}

\subsection{Empirical Model}

This study uses the standard country beta market model to measure the Indonesian country risk, as conducted by Gangemi et al. (2000), Andrade and Teles (2006), Verma and Soydemir (2006), Verbenik, et al. (2011), and also Basu et al. (2011) employ time-varying model of beta as shown in equation:

$$
\mathrm{R}_{\mathrm{IHSG}, \mathrm{t}}=\alpha+\beta \mathrm{R}_{\text {Equity World,t }}+\mathrm{e}_{\mathrm{t}}(1)
$$

where, $R_{I H S G, t}$ is return on Indonesia Stock Exchange, $\alpha$ and $\beta$ are the parameter, $R_{\text {Equity World,t }}$ is return on the global stock index and $e_{t}$ is the random disturbance term. Beta $(\beta)$ is used as 


\section{Macrothink}

the basis to measure the Indonesia Country Risk, in which this beta is influenced by combination of the internal and external macroeconomic factors.

The studies carried out by Fama and French (1989), also Mc-Queen and Roley (1993) stated that equity returns were closely related to the business cycle and such activities were influenced by macroeconomic variables. Further, Ferson and Harvey (1991), Jaganathan and Wang (1996) declared that the beta risk was the time-varying, and constitutes the part of business cycle. Based on the above argumentation, this study applies the time-varying model of beta as follows:

$$
\beta_{\mathrm{t}}=\mathrm{b}_{0}+\Sigma_{t=1}^{\mathrm{W}} \bar{t}_{\mathrm{t}} E_{t t}+\mathrm{u}_{\mathrm{t}}
$$

The equation of time-varying model of beta in this study is as follows:

$$
\begin{gathered}
\beta_{\mathrm{t}}=\mathrm{b}_{0}+\mathrm{b}_{1} \mathrm{NTR}_{\mathrm{t}}+\mathrm{b}_{2} \mathrm{SBI}_{\mathrm{t}}+\mathrm{b}_{3} \mathrm{INF}_{\mathrm{t}}+\mathrm{b}_{4} \mathrm{GRINDO}_{\mathrm{t}}+\mathrm{b}_{5} \mathrm{OIL}_{\mathrm{t}}+\mathrm{b}_{6} \text { FED }_{\mathrm{t}}+\mathrm{b}_{7} \text { GRDUNIA }_{\mathrm{t}}+ \\
\mathrm{b}_{8} \mathrm{FNBS}_{\mathrm{t}}+\mathrm{u}_{\mathrm{t}}
\end{gathered}
$$

The time-varying model of beta (3) cannot be estimated directly, therefore $\beta_{t}$ in equation (3) is substituted into the equation of Standard Country Beta Market Model (1) so that an equation is obtained as follows:

$$
\mathrm{R}_{\mathrm{IHSGt}}=\alpha+\beta_{\mathrm{t}} \mathrm{R}_{\mathrm{MSCI} \mathrm{t}}+\mathrm{e}_{\mathrm{t}}
$$

Further, the $\beta_{\mathrm{t}}$ at the equation (3) is substituted with the equation (4), so that we can obtain the time-varying beta market model applied to estimate the model of Indonesia country risk. The equation model applied in this research is as follows:

$$
\begin{array}{r}
\mathrm{R}_{\mathrm{IHSG}, \mathrm{t}}=\mathrm{a}+\left(\mathrm{b}_{0}+\mathrm{b}_{1} \mathrm{NTR}_{\mathrm{t}}+\mathrm{b}_{2} \mathrm{SBI}_{\mathrm{t}}+\mathrm{b}_{3} \mathrm{INF}_{\mathrm{t}}+\mathrm{b}_{4} \mathrm{GRINDO}_{\mathrm{t}}+\mathrm{b}_{5} \mathrm{OIL}+\mathrm{b}_{6} \mathrm{FED}_{\mathrm{t}}+\right. \\
\left.\mathrm{b}_{7} \mathrm{GRDUNIA}_{\mathrm{t}}+\mathrm{b}_{8} \mathrm{FNBS}_{\mathrm{t}}\right) \mathrm{R}_{\mathrm{MSCI}, \mathrm{t}}+\mathrm{e}_{\mathrm{t}}(5)
\end{array}
$$

or:

$$
\begin{aligned}
\mathrm{R}_{\mathrm{IHSG}, \mathrm{t}}=\mathrm{a}+\mathrm{b}_{0} \mathrm{R}_{\mathrm{MSCI}, \mathrm{t}}+\mathrm{b}_{1} \mathrm{NTR}_{\mathrm{t}} * \mathrm{R}_{\mathrm{MSCI}, \mathrm{t}}+\mathrm{b}_{2} \mathrm{SBI}_{\mathrm{t}} * \mathrm{R}_{\mathrm{MSCI}, \mathrm{t}}+\mathrm{b}_{3} \mathrm{INF}_{\mathrm{t}} * \mathrm{R}_{\mathrm{MSCI}, \mathrm{t}} \\
+\mathrm{b}_{4} \mathrm{GRINDO}_{\mathrm{t}} * \mathrm{R}_{\mathrm{MSCI}, \mathrm{t}}+\mathrm{b}_{5} \mathrm{OIL}_{\mathrm{t}} * \mathrm{R}_{\mathrm{MSCl}, \mathrm{t}}+\mathrm{b}_{6} \mathrm{FED}_{\mathrm{t}} * \mathrm{R}_{\mathrm{MSCI}, \mathrm{t}} \\
+\mathrm{b}_{7} \mathrm{GRDUNIA}_{\mathrm{t}} * \mathrm{R}_{\mathrm{MSCI}, \mathrm{t}}+\mathrm{b}_{8} \mathrm{FNBS}_{\mathrm{t}} * \mathrm{R}_{\mathrm{MSCI}, \mathrm{t}}+\mathrm{e}_{\mathrm{t}}(6)
\end{aligned}
$$

\section{Estimation and Result}

This study applies the VECM model to estimate the data from variables being studied. The application of VECM model with the time series requires several tests before estimating such VECM model. The first test to do is the stationery testing, namely by using the Augmented Dickey-Fuller (ADF). The procedure of this stationery test is carried out by comparing the probability value of ADF ( $\mathrm{p}$-value) and the critical value under the terms if ADF t-statistic is bigger than critical value at $\alpha=5 \%$, then such a data is said to be stationery (Mandala, 2005, p. 548). 


\section{Macrothink}

Table 2. Unit Root Test for Stationary

\begin{tabular}{|l|c|c|c|c|}
\hline \multirow{2}{*}{\multicolumn{1}{|c|}{ Variabel }} & \multicolumn{2}{c|}{ Level } & \multicolumn{2}{c|}{ First Difference } \\
\cline { 2 - 5 } & t-statistik & critical value 5\% & $\begin{array}{c}\text { t-statistik } \\
\text { ADF }\end{array}$ & critical value 5\% \\
\hline Return IHSG & $-4.268809^{*}$ & -2.938987 & $-3.836662^{*}$ & -1.949609 \\
\hline NTR*RMSCI & -2.606193 & -2.938987 & $-4.454861^{*}$ & -1.949609 \\
\hline SBI*RMSCI & -2.144295 & -2.938987 & $-4.092222^{*}$ & -1.949609 \\
\hline INF*RMSCI & $-3.687200^{*}$ & -2.938987 & $-3.686735^{*}$ & -1.949609 \\
\hline GRINDO*RMSCI & $-5.021868^{*}$ & -2.938987 & $-4.837831^{*}$ & -1.949609 \\
\hline OIL*RMSCI & $-4.944515^{*}$ & -2.938987 & $-4.725515^{*}$ & -1.949609 \\
\hline FED*RMSCI & -2.498023 & -2.941145 & $-3.922204^{*}$ & -1.949609 \\
\hline GRDUNIA*RMSCI & $-6.169604 *$ & -2.938987 & $-5.789056^{*}$ & -1.949609 \\
\hline FNBS*RMSCI & $-6.436192^{*}$ & -2.938987 & $-5.859868^{*}$ & -1.949609 \\
\hline Return MSCI & $-4.764237^{*}$ & -2.938987 & $-4.588113^{*}$ & -1.949609 \\
\hline
\end{tabular}

*denote significance level at $5 \%$

Based on the output of ADF Test, it is observed that the variables of NTR, SBI, and FED are not stationery at a certain level, in which ADF t-statistic is smaller than its critical values at the level of $5 \%$. Therefore, in order to obtain the stationery data, a differencing is carried out in the form of first difference and its result shows that all variables of ADF t-statistic value is bigger than the critical value at the level of $5 \%$.

The second test is carried out after the stationery data is obtained in order to determine the proper length of lag in VECM model. There are some criteria to determine the optimal lag, namely Likelihood Ratio (LR), Final Prediction Error (FPE), Akaike Information Criteria (AIC), Schwarz Information Criteria (SIC), and Hannah-Quinn Criteria (HQC). This study applies the AIC criteria with the lowest order of model to determine its optimal lag. The following is the outputs of optimum lag test:

Table 3. VAR Lag Order Selection

\begin{tabular}{|c|c|c|c|c|c|c|}
\hline Lag & LogL & LR & FPE & AIC & SC & HQ \\
\hline 0 & -35.22944 & NA & $5.12 \mathrm{e}-12$ & 2.380497 & $2.811441^{*}$ & $2.533823^{*}$ \\
\hline 1 & 44.16246 & 112.8201 & $1.80 \mathrm{e}-11$ & 3.465134 & 8.205515 & 5.151725 \\
\hline 2 & 207.0754 & $145.7642^{*}$ & $2.22 \mathrm{e}-12^{*}$ & $0.153925 *$ & 9.203743 & 3.373781 \\
\hline
\end{tabular}

* indicates lag order selected by criterion 


\section{Ml Macrothink}

Based on the aforesaid test result, it is found out that the optimum lag in this VECM model is available at the second order of AIC. This can be seen at the above table in which the value of the second order of AIC is lower compared to the other criteria of optimum lag. Thus, the AIC criteria in the second lag fulfills the requirement to carry out further analysis, namely performing the co-integrated test.

Third, this Johansen test is carried out by two statistics, namely Trace Test and Maximum Eigen Test. Under such a circumstance, if the Trace Test or the Maximum Eigen Test statistic has bigger value than the critical value of 0.05 , it means there is a co-integrated relationship among variables being tested. The following is the output of co-integrated test (the value of Max-Eigen Statistic):

Table 4. Johansen Cointegration Test

\begin{tabular}{|c|c|c|c|c|}
\hline $\begin{array}{c}\text { Hypothesized } \\
\text { No. of CE(s) }\end{array}$ & Eigenvalue & $\begin{array}{c}\text { Trace } \\
\text { Statistic }\end{array}$ & $\begin{array}{c}0.05 \\
\text { Critical Value }\end{array}$ & Prob.** \\
\hline None $*$ & 0.971036 & 460.0959 & 273.1889 & 0.0000 \\
\hline At most ${ }^{*}$ & 0.922253 & 325.5110 & 228.2979 & 0.0001 \\
\hline At most 2* & 0.845773 & 228.4476 & 187.4701 & 0.0001 \\
\hline At most 3 & 0.744817 & 157.4129 & 150.5585 & 0.0193 \\
\hline At most 4 & 0.594926 & 105.5135 & 117.7082 & 0.2281 \\
\hline At most 5 & 0.514862 & 71.17338 & 88.80380 & 0.4616 \\
\hline At most 6 & 0.344143 & 43.68713 & 63.87610 & 0.7064 \\
\hline At most 7 & 0.297241 & 27.65826 & 42.91525 & 0.6425 \\
\hline At most 8 & 0.256402 & 14.25408 & 25.87211 & 0.6366 \\
\hline At most 9 & 0.075824 & 2.996411 & 12.51798 & 0.8770 \\
\hline
\end{tabular}

*denotes rejection of the hypothesis at the 0,05 level

** MacKinnon-Haug-Michelis (1999) p-value

Based on the output of co-integrated test, it is shown that the value of Trace Statistic and Max-Eigen is bigger than the critical value of 0.05 , so that it can be concluded that the aforesaid data are cointegrated. This indicates that there is a long term relationship between variables applied in this research and the country risk. The co-integration of a data indicates a proper signal to apply the VECM model.

Estimation output of the Indonesia country risk using the VECM method gets the long term and the short term coefficients. The output of the long term VECM estimation is as follows: 
Table 5. Result of VECM in the Long Run

\begin{tabular}{|c|c|}
\hline Cointegrating Eq: & CointEq1 \\
\hline RETURN_IHSG(-1) & 1.000000 \\
\hline \multirow[t]{2}{*}{ NTR*RMSCI(-1) } & 0.005601 \\
\hline & {$[13.7407]^{*}$} \\
\hline \multirow[t]{2}{*}{ SBI*RMSCI(-1) } & 2.709230 \\
\hline & {$[6.66158]^{*}$} \\
\hline \multirow[t]{2}{*}{ INF*RMSCI(-1) } & -1.850480 \\
\hline & {$[-9.46841]^{*}$} \\
\hline \multirow[t]{2}{*}{ GRINDO*RMSCI(-1) } & -2.201963 \\
\hline & {$[-6.87622]^{*}$} \\
\hline \multirow[t]{2}{*}{ OIL*RMSCI(-1) } & 0.011677 \\
\hline & {$[0.75436]$} \\
\hline \multirow[t]{2}{*}{ FED*RMSCI(-1) } & -2.062963 \\
\hline & {$[-9.52235]^{*}$} \\
\hline \multirow[t]{2}{*}{ GRDUNIA*RMSCI(-1) } & 2.449573 \\
\hline & {$[13.2236]^{*}$} \\
\hline \multirow[t]{3}{*}{ FNBS*RMSCI(-1) } & \\
\hline & 0.086711 \\
\hline & [ 1.49516$]$ \\
\hline \multirow[t]{2}{*}{ RETURN MSCI(-1) } & -52.56941 \\
\hline & {$[-8.82982]^{*}$} \\
\hline @TREND(04Q1) & -0.004838 \\
\hline $\mathrm{C}$ & 0.004470 \\
\hline
\end{tabular}

[] = t- statistic

$*$ denote significance level at $5 \%$ and df $31=(2,042)$

Based on the output of long term VECM estimation, its equation can be written as follows: 


\section{Macrothink}

$\mathrm{RIHSG}_{\mathrm{t}}=0.004470+0,00560 \mathrm{NTR} * \mathrm{RMSCI}_{\mathrm{t}}+2,70923 \mathrm{SBI}^{*} \mathrm{RMSCI}_{\mathrm{t}}-1,85048$

INF*RMSCI $\mathrm{t}_{t}-2,2019$ GRINDO*RMSCI + 0,01167 OIL*RMSCI $\mathrm{I}_{t}-2.0629 \mathrm{FED}_{\mathrm{t}} * \mathrm{RMSCI}_{\mathrm{t}}+$

2.44957 GRDUNIA*RMSCI ${ }_{t}+0.086711$ FNBS*RMSCI $_{t}-52.56941$ RMSCI $_{t}$

Output of the long term VECM estimation indicates that the exchange rate of Rupiah to US Dollar (NTR*RMSCI), the interest rate of SBI for 6 months (SBI*RMSCI), the world oil price (OIL*RMSCI), the world economic growth (GRDUNIA*RMSCI), foreign transaction value (FNBS*RMSCI) have positive influence to the country risk in Indonesia. Inflation variable, Indonesia economic growth (GRINDO*RMSCI), Fed Fund Rate (FED*RMSCI) and the return of MSCI ACWI IMI have negative influence to the country risk in Indonesia.

Output of the short term VECM estimation is shown as follows: 
Table 7. Result of VECM in the Short Term

\begin{tabular}{|c|c|}
\hline Error Correction & $\mathrm{D}$ (Return IHSG) \\
\hline \multirow[t]{2}{*}{ CointEq1 } & -0.346688 \\
\hline & {$[-3.97142]$} \\
\hline \multirow[t]{2}{*}{ D(RETURN IHSG(-1)) } & -0.307200 \\
\hline & {$[-1.43631]$} \\
\hline \multirow[t]{2}{*}{ D(NTR*RMSCI(-1)) } & 0.001606 \\
\hline & [2.92200]* \\
\hline \multirow[t]{2}{*}{ D(SBI*RMSCI(-1)) } & 0.677907 \\
\hline & {$[2.32540]^{*}$} \\
\hline \multirow[t]{2}{*}{ D(INF*RMSCI(-1)) } & -0.359988 \\
\hline & {$[-1.99084]$} \\
\hline \multirow[t]{2}{*}{ D(GRINDO*RMSCI(-1)) } & 0.077975 \\
\hline & {$[0.19552]$} \\
\hline \multirow[t]{2}{*}{ D(OIL*RMSCI(-1)) } & 0.020491 \\
\hline & [ 1.82674$]$ \\
\hline \multirow[t]{2}{*}{ D(FED*RMSCI(-1)) } & -0.492326 \\
\hline & {$[-2.60995]^{*}$} \\
\hline \multirow[t]{2}{*}{ D(GRDUNIA*RMSCI(-1)) } & 0.477636 \\
\hline & {$[2.17530]^{*}$} \\
\hline \multirow[t]{2}{*}{ D(FNBS*RMSCI(-1)) } & -0.055585 \\
\hline & {$[-0.76023]$} \\
\hline \multirow[t]{2}{*}{ D(RETURN MSCI(-1)) } & -20.39836 \\
\hline & {$[-3.00523]^{*}$} \\
\hline \multirow[t]{2}{*}{$\mathrm{C}$} & 0.034365 \\
\hline & {$[0.87108]$} \\
\hline
\end{tabular}

[ ] = t- statistic

$*$ denote significance level at $5 \%$ and df $31=(2,042)$ 
Based on the result of the said VECM estimation, the short term equation can be written as follows:

$\Delta$ RIHSG $_{\mathrm{t}}=0.0343-0.3466$ Coint.Eq $-0.3072 \Delta \mathrm{RIHSG}_{\mathrm{t}-1}+0.001606 \Delta \mathrm{NTR}^{*} \mathrm{RMSCI}_{\mathrm{t}-1}+$ $0.677907 \Delta \mathrm{SBI}^{*} \mathrm{RMSCI}_{\mathrm{t}-1}-0.359988 \Delta \mathrm{INF}^{*} \mathrm{RMSCI}_{\mathrm{t}-1}+0.077975 \Delta$ GRINDO$^{*} \mathrm{RMSCI}_{\mathrm{t}-1}+$ $0.020491 \Delta \mathrm{OIL}^{*} \mathrm{RMSCI}_{\mathrm{t}-1}-0.492326 \Delta \mathrm{FED}^{*} \mathrm{RMSCI}_{\mathrm{t}-1}+0.477636 \Delta$ GRDUNIA $^{2} \mathrm{RMSCI}_{\mathrm{t}-1}$ $-0.055585 \Delta$ FNBS $^{*} \mathrm{RMSCI}_{\mathrm{t}-1}-20.39836 \Delta \mathrm{RMSCI}_{\mathrm{t}-1}(8)$

The above equation model indicates that for the short term, the exchange rate of Rupiah to US Dollar (NTR*RMSCI), the interest rate of SBI for 6 months (SBI*RMSCI), Indonesia economic growth (GRINDO*RMSCI), the world oil price (OIL*RMSCI), and the world economic growth (GRDUNIA*RMSCI) have positive influence to the country risk in Indonesia. Inflation (INF*RMSCI), Fed Fund Rate (FED*RMSCI) and foreign transaction value (FNBS*RMSCI) as well as the Return of MSCI have negative influence to the country risk in Indonesia.

The presence of co-integration between dependent variables and independent variables or the long term equilibrium enables to cause the occurrence of short term disequilibrium. This disequilibrium is frequently found at the economic behavior, meaning that what is needed by the economic doers is not always the same with what actually happens, so that an adjustment is required due to the said difference. The model including the adjustment for such equilibrium correction is called Error Correction Method (ECM). According to Gujarati and Porter (2010, p. 459), the speed of adjustment coefficient had the value from zero until one. Based on the output of short term VECM estimation, it is found out that the value of ECT is -0.34668 , and such value indicates that the disequilibrium is previously corrected at the current period at the amount of $0.34668 \%$. ECT indicates how fast the disequilibrium returns back to the long term equilibrium.

\section{Conclusion}

Based on the output of the long term VECM estimation, all variables of internal macro-economy significantly influence the country risk in Indonesia. However, output of the short term VECM estimation indicates that only the variables of exchange rate of Rupiah to US Dollar and the interest rate of SBI for 6 months have positive influence to the country risk in Indonesia. The internal factor having very great influence to the country risk in this study is the SBI interest rate in 6 months, namely at the amount of $2.70923 \%$. The Indonesia economic growth has negative significant to the country risk, namely at the amount of $2.2019 \%$. Inflation has negative significant influence to the country risk at the amount of $1.8504 \%$ and the variable having the smallest but significant influence to the country risk is the exchange rate of Rupiah to US Dollar, namely 0.0056 .

According to output of the long term VECM estimation, the external factors the having significant influence to the country risk in Indonesia are Fed Fund Rate, the world economic growth, and the return of MSCI ACWI IMI. The output of short term estimation indicates that variables having significant influence to the country risk are Fed Fund Rate and the return of MSCI ACWI IMI. The world economic growth significantly influences the country 
risk for the output of short term VECM estimation. The world oil price and foreign net buying/selling insignificantly influences the country risk based on the outputs of either long term or short term VECM estimation. The return of MSCI ACWI IMI has a great influence to the country risk in Indonesia, namely at the amount of $52.5694 \%$, so that this variable influences very much to the investors in making their decision to make investment in Indonesia. The variable with the smallest influence but significant to the country risk is Fed Fund Rate, namely at the amount of $2.0629 \%$.

Output of the long term or the short term VECM estimation for the MSCI ACWI IMI return has negative and significant influence to the country risk in Indonesia. MSCI ACWI IMI constituting the benchmark index of global market influences the country risk. This indicates the Indonesia Stock Market has a very close interconnection with the stock markets of other countries. The increase of MSCI ACWI IMI return causes the decrease of Indonesia country risk, so that it influences the decision of Investors to make investment in Indonesia.

\section{References}

Abell, J., \& Krueger, T. (1989). Macroeconomic Influences on Beta. Journal of Economics and Business, 41(2), 185-193. http://dx.doi.org/10.1016/0148-6195(89)90016-7

Akdeniz, L., Aslihan, A.S., \& Mehmet, C. (2003). Time-Varying Beta Help in Asset Pricing: The Threshold CAPM. Studies in Nonlinear Dynamics \& Econometrics, 6(4), 1-18. http://dx.doi.org/10.2202/1558-3708.1101

Andrade, J.P., \& Teles, V. K. (2006). An Empirical Model of the Brazilian Country Risk An Extension of the Beta Country Risk Model. Applied Economics, 38(11), 1271-1278. http://dx.doi.org/10.1080/00036840500426843

Barro, R.J., \& Gordon D.B. (1983). Rules, Discretion and Reputation in Model of Monetary Policy. Journal of Monetary Economics, 12(1), 101-121. http://dx.doi.org/10.3386/w1079

Basu, S., Deepthi, D., \& Reddy, J. (2011). Country Risk Analysis in Emerging Market: The Indian Example. Indian Institute of Management Bangalore Research Paper No. 326. http://dx.doi.org/10.2139/ssrn.2121340

Bilson, C.M.T.J., Brailsford \& Hooper, V.J. (2001). Selecting Macroeconomic Variables as Explanatory Factors of Emerging Stock Market Returns. Pacific-Basin Finance Journal, 9(4), 401-426. http://dx.doi.org/10.1016/S0927-538X(01)00020-8

Bruner, R.F. et al. (2008). Market integration in developed and emerging market Evidence from the CAPM. Emerging Market Review, 9(2), 89-103. http://dx.doi.org/10.1016/j.emermar.2008.02.002

Erb, C. B., Harvey, C. R., \& Viskanta, T. E. (1996a). Political Risk, Economic Risk and Financial Risk. Financial Analyst Journal, 52, 28-46. Spring. http://dx.doi.org/10.2139/ssm.7473

Erb, C. B., Harvey, C. R., \& Viskanta, T. E. (1996b). Expected Returns and Volatility in 135 Countries. Journal of Portfolio Management, 46-58. http://dx.doi.org/10.2139/ssm.871253 
Fama, E., \& French, K. (1989). Business Conditions and The Expected Returns On Stocks And Bonds. Journal of Financial Economics, 25, 23-50. http://dx.doi.org/10.1016/0304-405X(89)90095-0

Ferson, W., \& Harvey, C. (1991). The Variation of Economic Risk Premium. Journal of Political Economy, 99(2), 385-415.

Ferson, W., \& Harvey, C.R. (1994). Sources of Risk and Expected Returns in Global Equity Markets. Journal of Banking and Finance, 18(4), 775-803. http://dx.doi.org/10.3386/w4622

Gangemi, M.A.M., Brooks R.D., \& Faff, R.W. (2000). Modeling Australia's Country Risk: A Country Beta Approach. Journal of Economics and Business, 52(3), 259-276. http://dx.doi.org/10.1016/S0148-6195(99)00034-X

Grandes, M. R. (2002). Convergence and Divergence of Sovereign Bond Spreads: Theory and facts from Latin America. Technical Papers 2002 OECD Development Centre, Paris.

Gujarati, D.N. \& Porter, D.C. (2010). Essentials of Econometrics. Fourth Edition. New York: McGraw-Hill Education

Harvey, C. R. (1991). The World Price of Covariance Risk. Journal of Finance, 46(1), 111-157. http://dx.doi.org/10.1111/j.1540-6261.1991.tb03747.x

Harvey, C. R., \& Zhou, G. (1993). International Asset Pricing With Alternative Distributional Specifications. Journal of Empirical Finance, 1(1), 107-131.

Jagannathan, R., \& Wang, Z. (1996). The Conditional CAPM and the Cross-Section of Expected Returns. Journal of Finance, 51(1), 3-53. http://dx.doi.org/10.1111/j.1540-6261.1996.tb05201.x

Jeon, B.M. (2001). Macroeconomic Influence on Country Risk. Working Paper, Rice University.

Kharas, H. (1984). The long-run Creditworthiness of Developing Countries: Theory and Evidence. Quarterly Journal of Economics, 99(3), 415-439. http://dx.doi.org/10.2307/1885958

Lintner, J. (1965). The Valuation of Risk Assets and The Selections of Risky Investments in Stock Portfolio and Capital Budgets. Review of Economics and Statistic, 47(1), 13-37. http://dx.doi.org/10.2307/1924119

Manddala, G.S. (2005). Introduction to Econometrics. Third Edition. New York: John Wiley \& Son Ltd.

McQueen, G., \& Roley, V. (1993). Stock Prices, News, and Business Conditions. Review of Financial Studies, 6(3), 683-707. http://dx.doi.org/10.3386/w3520

Min, H.G., (1999). Determinants Of Emerging Marker Bond Spreads: Do Economic Fundamental Matter? Police Research Working Paper. http://dx.doi.org/10.1596/1813-9450-1899 


\section{Macrothink}

Asian Journal of Finance \& Accounting ISSN 1946-052X 2015, Vol. 7, No. 1

Mossin, J. (1966). Equilibrium in a Capital Asset Market. Modern Economy, 34(4), 768-783. http://dx.doi.org/10.2307/1910098

Oetzel, J.M., Betits, R.A., \& Zenner , M. (2001). Country risk measures: How risk are they? Journal of World Business, 36(2), 128-145.

Ross, et al. (2009). Modern Financial Management. Eight Edition, New York: McGraw-Hill International Edition.

Schill, M.J. (2008). New Perspectives on Investing in Emerging Markets. The Research Foundation of CFA Institute Literature Review.

Sharpe, W. (1964). Capital Asset Price: A Theory of Market Equilibrium under Conditions of $\begin{array}{llll}\text { Risk. Journal of } & \text { Finance, } & \text { 425-442. }\end{array}$ http://dx.doi.org/10.1111/j.1540-6261.1964.tb02865.x

Soussanov, D. (2002). Statistical Data Choice in Country Risk Analysis. Journal of Investing, 11(4), 39-42. http://dx.doi.org/10.3905/joi.2002.319523

Teixeira, M.F., Klotzle, M.C., \& Ness, W.L. (2008). Determinant Factor of Brazilian Country Risk: An Empirical Analysis of Specific Country Risk. Revista Brasileira de Financas, 6(1), 49-67.

Topak, M. S \& Muzir, Erol. (2011). Examination of Country Risk Determinants Using Artificial Neural Networks: The Case of Turkey. International Research Journal of Finance and Economics, 0(75), 120-131.

Verbenik, M., Horvath. J. , \& Gazda, V. (2011). Country risk in the New EU member states: A Country Beta Approach. International Research Journal of Finance and Economics, 10(80), 148-157.

Verma, R., \& Soydemir, G. (2006). Modeling Country Risk In Latin America: A country beta approach. Global Finance Journal, 17(2), 192-213. http://dx.doi.org/10.1016/j.gfj.2006.05.003

Vij, M., \& Kapoor, M.C. (2007). Country Risk Analysis: A Case Study of India. Journal of Management Research, 7(2), 87-102.

Wdowinski, P. (2004). Determinants of Country Beta in Poland. CESifo Working Paper Series, No. 1120. 